\title{
Permeability of dormant spores of Bacillus subtilis to malachite green and crystal violet
}

\author{
SATOSHI KoZUKA* and Kunio TochiKUBo \\ Department of Microbiology, Nagoya City University Medical School, Mizuho-ku, Nagoya, Aichi 467, Japan
}

(Received 26 June 1990; revised 10 October 1990; accepted 9 November 1990)

\begin{abstract}
The permeability of dormant spores of Bacillus subtilis to malachite green (MG) and crystal violet (CV) was examined by using potassium trichloro $\left(\eta^{2}\right.$-ethylene)platinum(II) (KTPt) as an electron-opaque marker for the dyes. The spores were treated with the dyes and other substances at $30{ }^{\circ} \mathrm{C}$ for $30 \mathrm{~min}$ or at $80{ }^{\circ} \mathrm{C}$ for $5 \mathrm{~min}$. When the spores were incubated in $50 \mathrm{mM}-\mathrm{MG}$ solution at $30^{\circ} \mathrm{C}$ and in $50 \mathrm{mM}-\mathrm{CV}$ solution at $30^{\circ} \mathrm{C}$ or $80^{\circ} \mathrm{C}$, many small electron-dense precipitates, which were chemical complexes of dyes and platinum, were seen, mainly around the boundary between the inner and outer coat regions. The spores treated under the above conditions were not stained. Treatment with $50 \mathrm{mM}$-MG alone or a mixture of $25 \mathrm{mM}$-oxalic acid and $50 \mathrm{mM}-\mathrm{CV}$ at $80{ }^{\circ} \mathrm{C}$ made the spores stainable and dye-TPt precipitates were observed mainly in the outer pericortex region. Pretreatment with 25 mMoxalic acid and $5 \%(\mathrm{v} / \mathrm{v})$ phenol at $80{ }^{\circ} \mathrm{C}$ followed by $50 \mathrm{~mm}-\mathrm{CV}$ treatment at $30^{\circ} \mathrm{C}$ gave the same results as above. It was considered from these results that the inner coat itself might function as the primary permeability barrier to MG and CV, and that a secondary barrier to the dyes might exist around the cortex region.
\end{abstract}

\section{Introduction}

Bacterial endospores are well known for their extreme resistance and dormancy. Previous studies related to the permeability of dormant spores to disinfectants (Sykes, 1970; Thomas \& Russell, 1974), polymyxin B (Tochikubo et al., 1986), lysozyme (Gould \& Hitchins, 1963; Gould et al., 1970) and germinants (Koshikawa et al., 1984; Vary, 1973; Watabe et al., 1974) indicate that a spore coat or an outer pericortex membrane may play an important role as a penetration barrier. Moreover, indirect evidence for the existence of a penetration barrier at or near the outer edge of the cortex has been obtained by electron microscopy of unfixed spores embedded in methacrylate (Rode et al., 1962). Recently, we showed by immunoelectron microscopy that the permeability barrier of dormant spores of Bacillus subtilis to gentamicin was present outside the cortex (Tochikubo et al., 1988).

Dormant spores cannot be stained by conventional methods for staining vegetative bacterial cells. Many investigators have noticed that acid treatment before staining (Fitz-James et al., 1954; Lechtman et al., 1965; Maneval, 1941; Robinow, 1951) or heat treatment

\footnotetext{
Abbreviations: CV, crystal violet; DAP, diaminopimelic acid; DPA, dipicolinic acid; GlcN, glucosamine; KTPt, potassium trichloro $\left(\eta^{2}-\right.$ ethylene)platinum(II); MG, malachite green.
}

during staining (Dorner, 1922; Dutton, 1928; May, 1926) is necessary to stain bacterial spores. In this paper, we report how far basic dyes can penetrate into $B$. subtilis spores and why the spores can be stained by the method of Schaeffer \& Fulton (1933), which is a simplification of a method proposed by Wirtz (1908).

\section{Methods}

Dormant spores. Dormant spores of B. subtilis PCI 219, prepared by growing the organism on nutrient agar at $37^{\circ} \mathrm{C}$ for $5 \mathrm{~d}$, were harvested and washed five times with sterile deionized water by centrifugation.

Treatment of dormant spores with dyes and other chemicals. Dormant spores (about $2 \times 10^{9} \mathrm{ml}^{-1}$ ) were suspended in an aqueous solution containing $50 \mathrm{~mm}$-crystal violet hydrochloride (CV; pH 3.9$)$ or $50 \mathrm{~mm}$ malachite green oxalate (MG; $\mathrm{pH} \mathrm{2.2)}$ and incubated at $30^{\circ} \mathrm{C}$ for 30 min or at $80^{\circ} \mathrm{C}$ for $5 \mathrm{~min}$. Dormant spores were also treated at $80^{\circ} \mathrm{C}$ for 5 min with $25 \mathrm{~mm}$-oxalic acid (pH 1.7), $50 \mathrm{~mm}$-CV plus $25 \mathrm{~mm}$-oxalic acid $(\mathrm{pH} 1.8)$ or $5 \%(\mathrm{v} / \mathrm{v})$ phenol ( $\mathrm{pH} 4.9)$, all of which were dissolved in deionized water. Afterwards they were washed at least five times with deionized water by centrifugation. For spores treated with oxalic acid or phenol this was followed by incubation in $50 \mathrm{mM}-\mathrm{CV}$ solution at $30^{\circ} \mathrm{C}$ for $30 \mathrm{~min}$ and washing with deionized water.

Determination of various properties of spores treated with dyes and other chemicals. Stainability of dye- or chemical-treated spores was observed by light microscopy and their refractility was examined by phase contrast microscopy. Germinability was determined by the loss of refractility of spores incubated at $37^{\circ} \mathrm{C}$ for $60 \mathrm{~min}$ on agar which was 
dissolved in $50 \mathrm{mM}$-phosphate buffer ( $\mathrm{pH} \mathrm{7.2)}$ and contained $50 \mathrm{mM}-\mathrm{L}-$ alanine. Lysozyme sensitivity was determined by suspending spores in $50 \mathrm{mM}$-Tris/ $\mathrm{HCl}$ buffer (pH 8.4) containing $200 \mu \mathrm{g}$ lysozyme $\mathrm{ml}^{-1}$ and measuring the decrease in $\mathrm{OD}_{650}$ after incubation at $37^{\circ} \mathrm{C}$ for $120 \mathrm{~min}$.

Electron microscopy and $X$-ray microanalysis. Treated spore samples were immersed in 50 mM-potassium trichloro $\left(\eta^{2}\right.$-ethylene)platinum (II) (KTPt) buffered with $50 \mathrm{mM}$-HEPES (pH 6.8) for $120 \mathrm{~min}$ at $37^{\circ} \mathrm{C}$ under reduced pressure. After washing three times with 50 mM-HEPES buffer by centrifugation, the pellets were fixed in a mixture of $8 \%(w / v)$ paraformaldehyde and $0.5 \%(\mathrm{v} / \mathrm{v})$ glutaraldehyde buffered with $100 \mathrm{mM}$-HEPES (pH 6.8) for $3 \mathrm{~d}$ at $4{ }^{\circ} \mathrm{C}$ under reduced pressure. They were washed twice in the same buffer and then suspended in molten $2 \%$ $(w / v)$ agar. After solidification, the agar was cut into $1 \mathrm{~mm}^{3}$ cubes. The agar cubes were dehydrated through increasing concentrations of Durcupan and embedded in modified Durcupan (Kushida, 1979); as a hardener, nonenyl succinic anhydride was substituted for 964 and 960 hardener of the original procedure (Stäubli, 1960). Polymerization was performed by heating at $60^{\circ} \mathrm{C}$ for $24 \mathrm{~h}$. After polymerization, sections were cut with a glass knife on a Reichert-Jung Ultracut $E$ ultramicrotome and mounted on Formvat-coated copper grids. The sections were observed without staining in a JEOL JEM-1200EX electron microscope at an accelerating voltage of $80 \mathrm{kV}$.

$\mathrm{X}$-ray spot microanalysis was performed on a Hitachi $\mathrm{H}-800$ electron microscope equipped with a Kevex-7000 Q energy dispersive system (EDS). Accelerating voltage was $100 \mathrm{kV}$, beam current $10^{-10} \mathrm{~A}$ and beam diameter $7 \mathrm{~nm}$. Selected area analysis was done on a square section $\left(0.04 \mu \mathrm{m}^{2}\right)$ for $100 \mathrm{~s}$. Platinum distribution maps were generated by interfacing the EDS with a scanning transmission electron microscope module and the cells were scanned for $400 \mathrm{~s}$ with the $\mathrm{Pt}$ $\left(\mathrm{M}_{\alpha, \beta}\right.$ and $\left.\mathrm{L}_{\alpha}\right)$ lines.

Biochemical analysis. About $1.3 \times 10^{10}$ spores treated with dyes and other chemicals were washed five times with distilled water by centrifugation using polycarbonate tubes treated with silicon to prevent their adherence. Afterwards they were autoclaved at $121^{\circ} \mathrm{C}$ for $20 \mathrm{~min}$ to measure the amounts of dipicolinic acid (pyridine-2,6-dicarboxylic acid, DPA) and calcium. DPA content was determined by the method of Scott \& Ellar (1978). Calcium content was measured by using a Hitachi model 180-50 atomic absorption spectrophotometer. For determination of amino acids, glucosamine ( $\mathrm{GlcN}$ ) and diaminopimelic acid (DAP), each treated spore sample was hydrolysed in $6 \mathrm{M}-\mathrm{HCl}$ at $100^{\circ} \mathrm{C}$ for $5 \mathrm{~h}$ with a Pico-Tag work station and the analyses were performed with a JEOL JLC-300 high-speed amino acid analyser equipped with an LC30-DK20 data-processing system using lithium citrate buffer. Total protein content was calculated from the data obtained in the amino acid analysis.

Chemicals. CV and MG were purchased from Merck, oxalic acid and phenol from Katayama Kagaku Industrial Co., KTPt from Aldrich, lysozyme from Boehringer Mannheim, HEPES from Dojindo Laboratories, paraformaldehyde, glutaraldehyde and nonenyl succinic anhydride from TAAB, and Durcupan from Fluka.

\section{Results}

Electron microscopy of $B$. subtilis spores treated with $M G$ and $C V$

Thin sections of untreated spores immersed only in KTPt solution demonstrated no electron-dense precipitates (Fig. 1a), whereas those of spores treated with MG or $\mathrm{CV}$ at $30^{\circ} \mathrm{C}$ for $30 \mathrm{~min}$ and subsequently immersed in
KTPt solution showed small electron-dense precipitates, which seemed to be the MG-TPt or CV-TPt deposits, preferentially localized in the outer coat region but not in the inner coat, cortex and core regions (Fig. $1 b$ ). When the spores were treated with $\mathrm{MG}$ at $80^{\circ} \mathrm{C}$ for $5 \mathrm{~min}$, large amounts of MG-TPt deposits were mainly observed in the outer pericortex region (Fig. 2a), suggesting that MG could penetrate the spore coat but not the cortex; in this thin section the contour of the core was clear in company with crystal-like substances.

On the other hand, when spores were treated with CV alone at $80^{\circ} \mathrm{C}$ for $5 \mathrm{~min}$ the CV-TPt deposits were observed only in the outer coat region in the same manner as the spores treated at $30^{\circ} \mathrm{C}$ (data not shown). This difference between the two dyes seemed to be due to oxalate because of its presence in the MG reagent and it was therefore assumed that oxalate must play an important role in penetration of MG into the outer pericortex region. To clarify this, spores were incubated in a mixture of $\mathrm{CV}$ and oxalic acid at $80^{\circ} \mathrm{C}$ for $5 \mathrm{~min}$. The CV-TPt precipitates were formed between the inner coat and cortex regions, as in the spores treated with $\mathrm{MG}$ at $80^{\circ} \mathrm{C}$ (Fig. 2 b); pretreatment with oxalic acid at $80^{\circ} \mathrm{C}$ for $5 \mathrm{~min}$ and subsequent treatment with $\mathrm{CV}$ showed the same result (data not shown) and crystal-like substances were also observed in a thin section of the spores treated with oxalic acid alone (data not shown). Pretreatment with phenol at $80^{\circ} \mathrm{C}$ for $5 \mathrm{~min}$ in place of oxalic acid, followed by $\mathrm{CV}$ treatment at $30^{\circ} \mathrm{C}$ for $30 \mathrm{~min}$, also showed the same result as $\mathrm{MG}$ treatment at $80^{\circ} \mathrm{C}$ and $\mathrm{CV} /$ oxalic acid treatment at $80^{\circ} \mathrm{C}$ (Fig. $2 c$ ).

To ascertain whether the small electron-dense precipitates formed in the outer pericortex region contained $\mathrm{Pt}$, $\mathrm{X}$-ray spot microanalysis was performed on a thin section of a spore treated with $\mathrm{MG}$ at $80^{\circ} \mathrm{C}$ for $5 \mathrm{~min}$. The X-ray spectrum indicated the presence of $\mathrm{Pt}$ (data not shown). Additionally, the distribution of $\mathrm{Pt}$ in thin sections of spores treated with $\mathrm{MG}$ at $30^{\circ} \mathrm{C}$ and $80^{\circ} \mathrm{C}$ was examined. Spores treated at $30^{\circ} \mathrm{C}$ showed the presence of $\mathrm{Pt}$ mainly in the coat region, whereas those treated at $80^{\circ} \mathrm{C}$ showed the presence of $\mathrm{Pt}$ throughout the spore, including the core and cortex regions (data not shown); the distribution map of spores treated with $\mathrm{KTPt}$ alone at 30 and $80^{\circ} \mathrm{C}$ indicated that Pt mainly localized in the coat region, and that of spores treated with oxalic acid at $80^{\circ} \mathrm{C}$ showed the presence of $\mathrm{Pt}$ throughout the spore. These results suggest that when the spores were stained with $\mathrm{MG}$ at $80^{\circ} \mathrm{C}$, the $\mathrm{Pt}$ label could penetrate into the core region but the dye could only penetrate to the outer pericortex region.

To check the reproducibility and repeatability of the above results, the same experiments were carried out three times and 500 thin sections of each preparation of treated spores were examined. The proportions of thin 

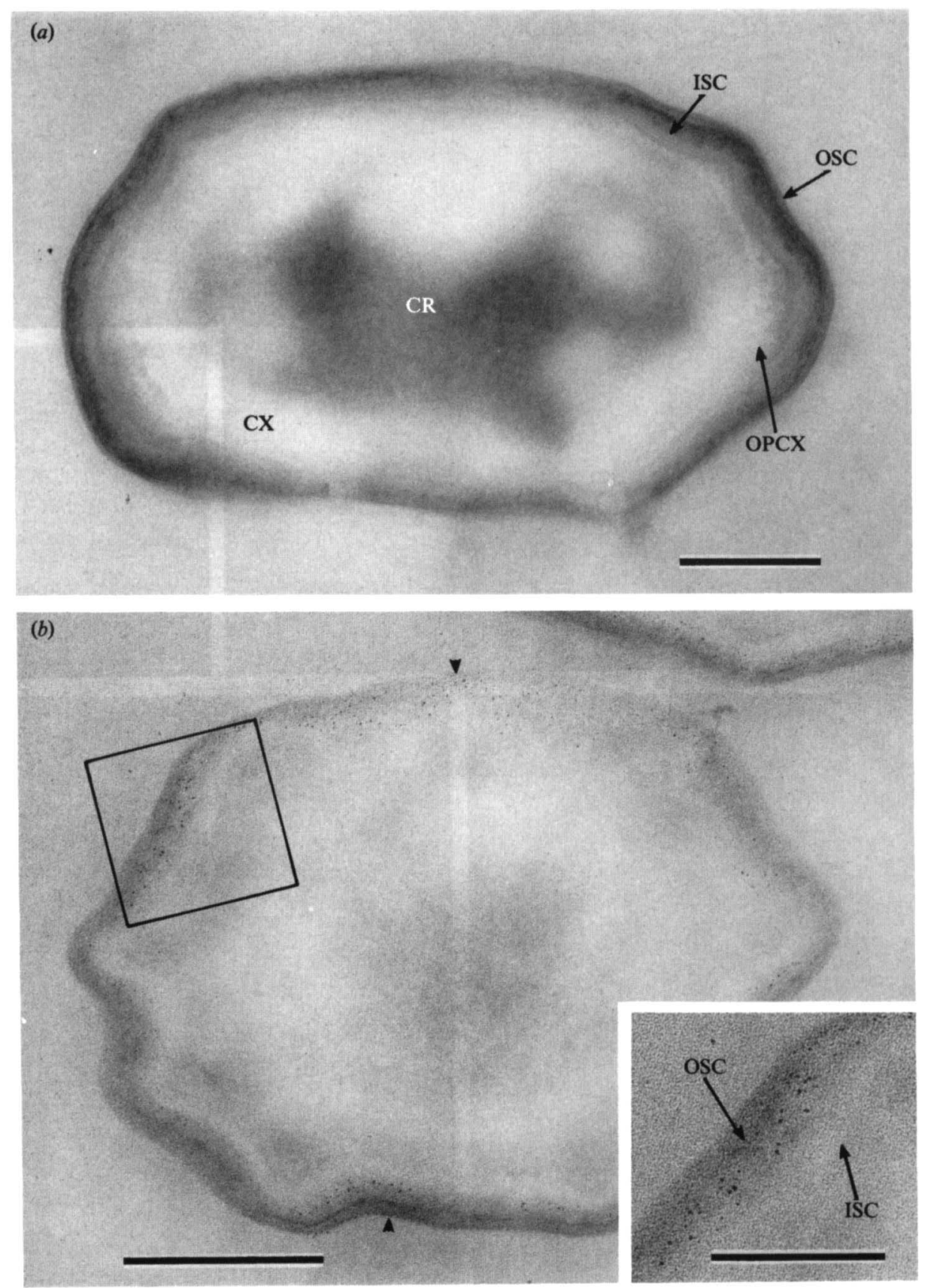

Fig. 1. Electron micrographs of thin sections of untreated spores $(a)$, and spores treated with $\mathrm{CV}$ at $30^{\circ} \mathrm{C}$ for 30 min $(b)$. Arrowheads in (b) indicate CV-TPt precipitates. A highly magnified picture of the integument ( $b$, inset) clearly shows that platinum deposits are formed in the spore coat region. OSC, outer spore coat; ISC, inner spore coat; OPCX, outer pericortex; CX, cortex; CR, core. Bars represent $200 \mathrm{~nm}$ (inset, $100 \mathrm{~nm}$ ).

sections showing large amounts of MG- or CV-TPt deposits in the outer pericortex region were $71 \cdot 6 \pm 1.9 \%$ with MG treatment at $80{ }^{\circ} \mathrm{C}, 73 \cdot 1 \pm 2 \cdot 3 \%$ with $\mathrm{CV} /$ oxalic acid treatment at $80^{\circ} \mathrm{C}$ and $87.2 \pm 3.3 \%$ with phenol/CV treatment at $80^{\circ} \mathrm{C}$ (mean $\pm \mathrm{SD}$ ), suggesting that the results obtained are reproducible.
Effect of $M G, C V$, oxalic acid and phenol on various properties of $B$. subtilis spores

Spores treated with MG or $\mathrm{CV}$ at $30^{\circ} \mathrm{C}$ for $30 \mathrm{~min}$ or with $\mathrm{CV}$ at $80^{\circ} \mathrm{C}$ for $5 \mathrm{~min}$ remained refractile, unstained and germinable by L-alanine, and were not 

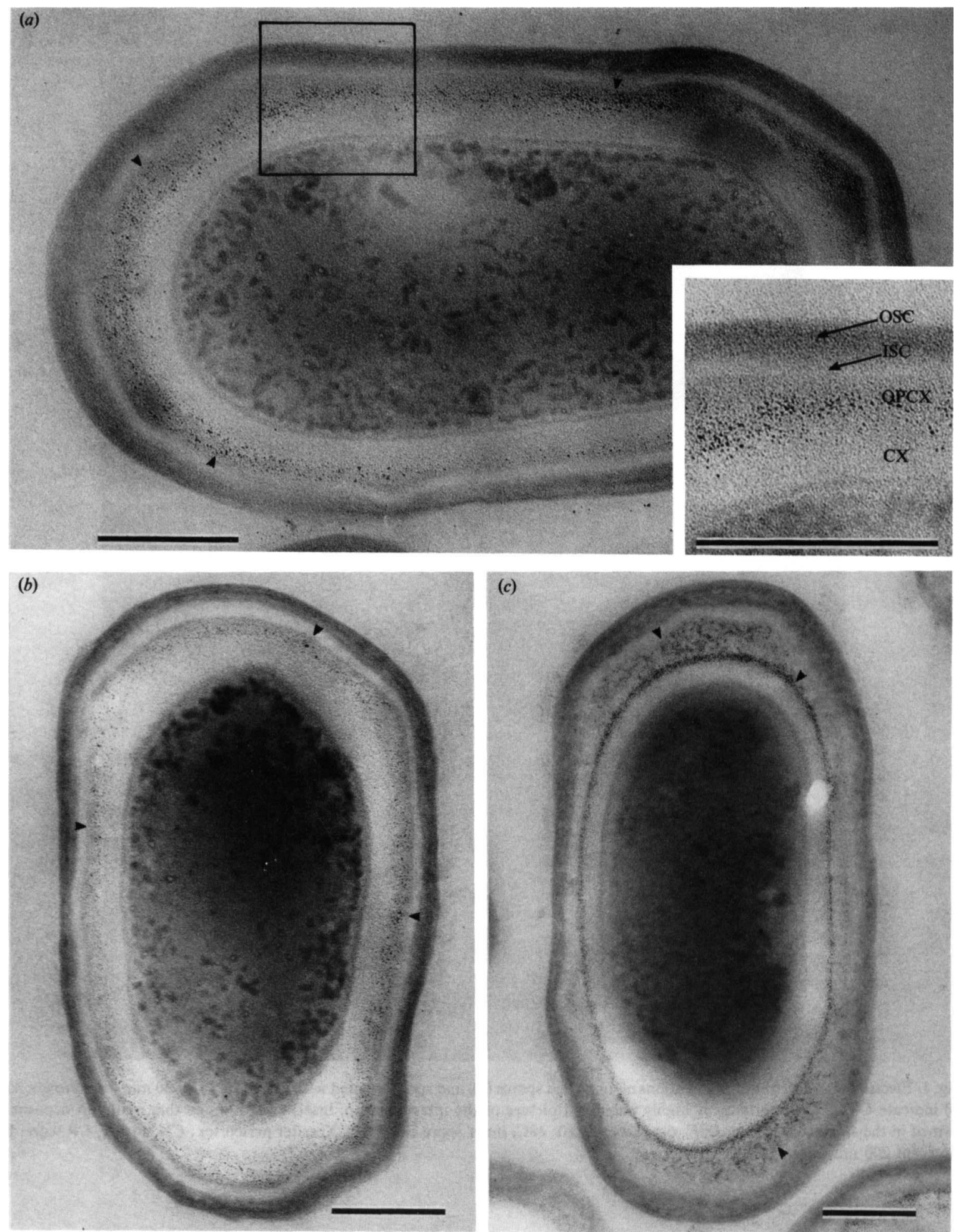

Fig. 2. Typical electron micrographs of thin sections of spores treated with $\mathrm{MG}$ at $80^{\circ} \mathrm{C}$ for $5 \mathrm{~min}(\mathrm{a})$, spores treated with a mixture of $\mathrm{CV}$ and oxalic acid at $80^{\circ} \mathrm{C}$ for $5 \mathrm{~min}(b)$ and spores treated with $\mathrm{CV}$ after pretreatment with phenol at $80^{\circ} \mathrm{C}$ for 5 min $(c)$. Arrowheads indicate MG-TPt or CV-TPt precipitates. A highly magnified picture of the integument $(a$, inset) clearly shows that platinum deposits are formed in the outer pericortex region. OSC, outer spore coat; ISC, inner spore coat; OPCX, outer pericortex; CX, cortex. Bars represent $200 \mathrm{~nm}$. 
Table 1. Some properties of dye- or chemical-treated spores of B. subtilis

Spores remained refractile after each of the treatments.

\begin{tabular}{|c|c|c|c|}
\hline Treatment & Stainability & $\begin{array}{c}\text { Germinability } \\
\text { by L-alanine }\end{array}$ & $\begin{array}{l}\text { Lysozyme } \\
\text { sensitivity }\end{array}$ \\
\hline None & & + & - \\
\hline \multicolumn{4}{|l|}{ CV } \\
\hline $30^{\circ} \mathrm{C}, 30 \mathrm{~min}$ & Unstained & + & - \\
\hline \multirow{2}{*}{\multicolumn{4}{|c|}{ MG }} \\
\hline & & & \\
\hline $30^{\circ} \mathrm{C}, 30 \mathrm{~min}$ & Unstained & + & - \\
\hline $80^{\circ} \mathrm{C}, 5 \mathrm{~min}$ & Stained & - & + \\
\hline \multicolumn{4}{|l|}{ Oxalic acid } \\
\hline $30^{\circ} \mathrm{C}, 30 \mathrm{~min}$ & $\begin{array}{l}\text { Unstained wth } \\
\mathrm{CV} \text { at } 30^{\circ} \mathrm{C}\end{array}$ & + & - \\
\hline $80^{\circ} \mathrm{C}, 5 \mathrm{~min}$ & $\begin{array}{l}\text { Stained with } \\
\mathrm{CV} \text { at } 30^{\circ} \mathrm{C}\end{array}$ & - & + \\
\hline \multicolumn{4}{|l|}{ Phenol } \\
\hline $30^{\circ} \mathrm{C}, 30 \mathrm{~min}$ & $\begin{array}{l}\text { Unstained with } \\
\mathrm{CV} \text { at } 30^{\circ} \mathrm{C}\end{array}$ & + & - \\
\hline $80^{\circ} \mathrm{C}, 5 \mathrm{~min}$ & $\begin{array}{l}\text { Stained with } \\
\mathrm{CV} \text { at } 30^{\circ} \mathrm{C}\end{array}$ & - & + \\
\hline
\end{tabular}

Table 2. Contents of DPA, calcium, GlcN, DAP and total protein in spores treated with oxalic acid, phenol or $M G$

\begin{tabular}{|c|c|c|c|c|c|}
\hline \multirow[b]{2}{*}{ Treatment } & \multicolumn{5}{|c|}{ Content ( $\mu$ g per approx. $1.3 \times 10^{10}$ spores) of: } \\
\hline & DPA & Calcium & GlcN & DAP & Total protein \\
\hline None & $\begin{array}{c}365 \cdot 0 \pm 13 \cdot 8 \\
(100)\end{array}$ & $\begin{array}{c}98 \cdot 9 \pm 12 \cdot 0 \\
(100)\end{array}$ & $\begin{array}{c}163.4 \pm \\
(100)\end{array}$ & $\begin{array}{c}77.3 \pm 1.9 \\
(100)\end{array}$ & $\begin{array}{c}2711 \cdot 4 \pm 81 \cdot 6 \\
(100)\end{array}$ \\
\hline $\begin{array}{l}\text { Oxalic acid } \\
\left(80^{\circ} \mathrm{C}, 5 \mathrm{~min}\right)\end{array}$ & ${ }_{(3.9)}^{14 \cdot 3 \pm} 2 \cdot 1$ & $\begin{array}{c}15 \cdot 9 \pm 9 \cdot 4 \\
(16 \cdot 1)\end{array}$ & $\begin{array}{c}153 \cdot 0 \pm 8.5 \\
(93 \cdot 6)\end{array}$ & $\begin{array}{c}73.9 \pm 1.6 \\
(95.6)\end{array}$ & $\begin{array}{c}2276 \cdot 3 \pm 78 \cdot 4 \\
(84 \cdot 0)\end{array}$ \\
\hline $\begin{array}{l}\text { Phenol } \\
\left(80^{\circ} \mathrm{C}, 5 \mathrm{~min}\right)\end{array}$ & $\begin{array}{c}41 \cdot 8 \pm 4 \cdot 4 \\
(11 \cdot 5)\end{array}$ & $\begin{array}{c}13 \cdot 9 \pm 8 \cdot 8 \\
(14 \cdot 1)\end{array}$ & ${ }_{(86.9)}^{142.0 \pm 9.5}$ & ${ }_{(86 \cdot 8)}^{67.1 \pm}$ & $\begin{array}{c}2186 \cdot 7 \pm 87.5 \\
(80 \cdot 6)\end{array}$ \\
\hline $\begin{array}{l}\text { MG } \\
\left(80^{\circ} \mathrm{C}, 5 \mathrm{~min}\right)\end{array}$ & $\begin{array}{c}17.0 \pm 3.4 \\
(4 \cdot 7)\end{array}$ & $\begin{array}{c}13 \cdot 8 \pm 10 \cdot 1 \\
(14 \cdot 0)\end{array}$ & $\begin{array}{c}138.4 \pm 12 \cdot 9 \\
(84 \cdot 7)\end{array}$ & $\begin{array}{c}67 \cdot 1 \pm \\
(86 \cdot 8)\end{array}$ & $\begin{array}{c}2055.8 \pm 221.8 \\
(75.8)\end{array}$ \\
\hline
\end{tabular}

* Each value represents the mean $\pm \mathrm{SD}$ of three determinations. Numbers in parentheses are percentages of the control values.

sensitive to lysozyme (Table 1). Pretreatment with oxalic acid or phenol at $30^{\circ} \mathrm{C}$ gave the same results. On the other hand, spores that were either dyed green by MG treatment at $80^{\circ} \mathrm{C}$ for $5 \mathrm{~min}$, or violet by $\mathrm{CV}$ treatment at $30^{\circ} \mathrm{C}$ for $30 \mathrm{~min}$ following initial pretreatment with oxalic acid or phenol at $80^{\circ} \mathrm{C}$ for $5 \mathrm{~min}$, retained their refractility but lost their germinability by $L$-alanine and became sensitive to lysozyme (Table 1). These results paralleled those obtained by electron microscopy.

\section{Chemical composition of treated spores}

The contents of DPA, calcium, GlcN, DAP and protein of spores treated with oxalic acid, phenol or MG-oxalate at $80^{\circ} \mathrm{C}$ for $5 \mathrm{~min}$ were examined because these chemicals could make them stainable. Considerable amounts of DPA and calcium were lost during treatment with $\mathrm{MG}$ at $80^{\circ} \mathrm{C}$ and pretreatment with oxalic acid or phenol at $80^{\circ} \mathrm{C}$, but the contents of GlcN and DAP, 
which are components of the cortex, and protein were close to those for untreated spores (Table 2). As the measured values shown in Table 2 were based on the original amount of spores treated, some of the losses of GlcN, DAP and protein could be accounted for by incomplete recovery of spores during the centrifugation process. In addition DPA and calcium might be lost to some extent.

\section{Discussion}

In this paper we have demonstrated by using a new electron-opaque probe, $\mathrm{KTPt}$, that MG and CV must penetrate the spore coat and reach the outer pericortex region for dyed spores to be observed by light microscopy.

When the spores of $B$. subtilis were subjected to MG treatment at $80^{\circ} \mathrm{C}$ for $5 \mathrm{~min}$, conditions judged to be almost identical to those of Schaeffer and Fulton's method of spore staining (Schaeffer \& Fulton, 1933), followed by immersion in KTPt solution, they were stained green (Table 1) and many small electron-dense precipitates were observed in the outer pericortex region (Fig. 2a). It has already been reported that the TPt anion complexes with $\mathrm{CV}^{+}$to produce a CV-TPt precipitate (Beveridge \& Davies, 1983; Davies et al., 1983). Since MG is a triphenyl methane compound like $\mathrm{CV}$, though a weak basic dye, it must be able to form a MG-TPt precipitate. In fact, in our preliminary experiment $M G$ reacted with $\mathrm{KTPt}$ to produce a MG-TPt precipitate in vitro and it was ascertained by $\mathrm{X}$-ray microanalysis that the small electron-dense precipitates observed in thin sections contained Pt. Therefore it seems reasonable to consider that the small electron-dense deposits formed in the outer pericortex region consist of MG-TPt complex. The same result was also obtained by treatment with a mixture of CV and oxalic acid at $80^{\circ} \mathrm{C}$ for $5 \mathrm{~min}$ (Fig. $2 \mathrm{~b}$ ) and by pretreatment with oxalic acid or phenol at a high temperature and subsequent CV treatment (Fig. 2c).

Many methods of spore staining other than that of Schaeffer \& Fulton (1933), which is a simplification of a method proposed by Wirtz (1908), need a mordant such as chromic acid (May, 1926; Möller, 1891), nitric acid (Lechtman et al., 1965), osmic acid (Wirtz, 1908), ammonia (Lagerberg, 1917), or a mixture of phenol, acetic acid and ferric chloride (Maneval, 1941). In our experiments MG oxalate was employed and pretreatment with oxalic acid or phenol at $80^{\circ} \mathrm{C}$ was necessary for spore staining with CV (Table 1). Oxalic acid and phenol also seemed to act as a mordant and the heating step was essential in this case.

When the spores were treated with $\mathrm{MG}$ or $\mathrm{CV}$ at room temperature and immersed in the KTPt solution, they were not stained and MG-TPt or CV-TPt precipitates were formed in the outer coat region, especially around the boundary between the inner and outer coat regions (Fig. $1 b$ ). This fact seems to suggest the existence of the primary permeability barrier to the dyes between these two regions. Ohye \& Murrell (1962) reported that $\mathrm{OsO}_{4}$ penetrates poorly beneath the outer coat of dormant spores of Bacillus coagulans. Alternatively, the inner coat itself may function as the permeability barrier and pretreatment with oxalic acid or phenol at a high temperature may cause partial destruction of the inner coat layer and enable the dyes to reach the outer pericortex region because spores treated with oxalic acid or phenol became susceptible to lysozyme (Table 1). Failure of the dyes to penetrate the cortex suggests the existence of a secondary permeability barrier, that is, an outer membrane, which has been demonstrated biochemically in the spores of Bacillus megaterium (CraftsLighty \& Ellar, 1980), by the morphological observation of variant spores lacking an exosporium (Koshikawa et al., 1984) and by showing the presence of vegetative cell membrane derived proteins in the spore coat of $B$. subtilis (Fujita et al., 1989). However, the localization and the integration of an outer membrane remain unclear with $B$. subtilis spores. Beaman et al. (1988) have reported the permeabilization of the outer membrane of Bacillus stearothermophilus spores by heat shock at 100 or $80^{\circ} \mathrm{C}$ as shown by the susceptibility to lysozyme action and permeation of Nycodenz.

Spores treated with MG oxalate, oxalic acid or phenol at a high temperature lost large amounts of DPA and calcium (Table 2) and became susceptible to lysozyme but retained their characteristic refractility (Table 1). The same phenomena have been reported for the spores of $B$. megaterium (Rode \& Foster, 1960) and the fully activated spores of $B$. stearothermophilus (Beaman et al., 1988). Treatment with the above chemicals seemed not to affect the cortex because little loss of GlcN and DAP was observed (Table 2).

We thank Takamasa Hanaichi of the Electron Microscope Center, Nagoya University School of Medicine, for performing the X-ray analyses.

\section{References}

Beaman, T. C., Pankratz, H. S. \& Gerhardt, P. (1988). Heat shock affects permeability and resistance of Bacillus stearothermophilus spores. Applied and Environmental Microbiology 54, 2515-2520.

BEVERIDGe, T. J. \& DAVIES, J. A. (1983). Cellular responses of Bacillus subtilis and Escherichia coli to the gram stain. Journal of Bacteriology 156, 846-858.

Crafts-Lighty, A. \& Ellar, D. J. (1980). The structure and function of the spore outer membrane in dormant and germinating spores of Bacillus megaterium. Journal of Applied Bacteriology 48, 135-145. 
Davies, J. A., Anderson, G. K., Beveridge, T. J. \& Clark, H. C. (1983). Chemical mechanism of the gram stain and synthesis of a new electron-opaque marker for electron microscopy which replaces the iodine mordant of the stain. Journal of Bacteriology 156, 837-845.

DORNER, W. (1922). Ein neues Verfahren für isolierte Sporenfärbung. Landwirtschaftliches Jahrbuch der Schweiz 36, 595-597.

DutTon, L. O. (1928). Wright's as a differential spore stain. Stain Technology 3, 140-142.

Fitz-James, P. C., Robinow, C. F. \& Bergold, G. H. (1954). Acid hydrolysis of the spores of $B$. cereus: a correlation of chemical and cytological findings. Biochimica et Biophysica Acta 14, 346355.

Fujita, Y., Yasuda, Y., Kozuka, S. \& Tochikubo, K. (1989). Presence of proteins derived from the vegetative cell membrane in the dormant spore coat of Bacillus subtilis. Microbiology and Immunology 33, 391-401.

GouLD, G. W. \& Hitchins, A. D. (1963). Sensitization of bacterial spores to lysozyme and to hydrogen peroxide with agents which rupture disulphide bonds. Journal of General Microbiology 33, 413-423.

Gould, G. W., StubBs, J. M. \& KING, W. L. (1970). Structure and composition of resistant layers in bacterial spore coats. Journal of General Microbiology 60, 347-355.

Koshikawa, T., Beaman, T. C., Pankratz, H. S., Nakashio, S., CORNER, T. R. \& GerhardT, P. (1984). Resistance, germination, and permeability correlates of Bacillus megaterium spores successively divested of integument layers. Journal of Bacteriology 159, 624-632.

KUSHIDA, H. (1979). Ultrathin sectioning (5). Saibo 11, 350-352 (in Japanese).

LAGERBERG, I. (1917). Eine neue Methode der Sporenfärbung nebst Bemerkung über saurefeste Granula in sporenhaltigen Bakterien. Zentralblatt für Bakteriologie, Parasitenkunde und Infektionskrankheiten. Abteilung 1, Originale 79, 191-192.

Lechtman, M. D., Bartholomew, J. W., Philips, A. \& Russo, M. (1965). Rapid methods of staining bacterial spores at room temperature. Journal of Bacteriology 89, 848-854.

MANEVAL, W. E. (1941). Staining bacteria and yeasts with acid dyes. Stain Technology 16, 13-19.

MAY, H. G. (1926). A safe spore stain for class use. Stain Technology 1 , 105-106.
MöLleR, H. (1891). Über eine neue Methode der Sporenfärbung. Zentralblatt für Bakteriologie, Parasitenkunde und Infektionskrankheiten. Abteilung 1, Originale 10, 273-277.

OHYE, D. F. \& MURRELL, W. G. (1962). Formation and structure of the spore of Bacillus coagulans. Journal of Cell Biolology 14, 111-123.

RoBinow, C. F. (1951). Observations on the structure of Bacillus spores. Journal of General Microbiology 5, 439-457.

RODE, L. J. \& FOSTER, J. W. (1960). Induced release of dipicolinic acid from spores of Bacillus megaterium. Journal of Bacteriology 79, 650-656.

RoDe, L. J., LeWIS, C. W. \& FosTER, J. W. (1962). Electron microscopy of spores of Bacillus megaterium with special reference to the effects of fixation and thin sectioning. Journal of Cell Biology 13, 423-435.

Schaeffer, A. B. \& Fulton, M. D. (1933). A simplified method of staining endospores. Science 77, 194.

SCOTT, I. R. \& EllaR, D. J. (1978). Study of calcium dipicolinate release during bacterial spore germination by using a new, sensitive assay for dipicolinate. Journal of Bacteriology 135, 133-137.

STÄUBLI, W. (1960). Nouvelle matière d'inclusion hydrosoluble pour la cytologie électronique. Comptes Rendus Hebdomadaires des Séances de l'Académie des Sciences 250, 1137-1139.

SYKES, G. (1970). The sporicidal properties of chemical disinfectants. Journal of Applied Bacteriology 33, 147-156.

Thomas, S. \& Russell, A. D. (1974). Studies on the mechanism of the sporicidal action of glutaraldehyde. Journal of Applied Bacteriology 37, 83-92.

TochixuBo, K., Yasuda, Y. \& KozuKa, S. (1986). Decreased particulate NADH oxidase activity in Bacillus subtilis spores after polymyxin B treatment. Journal of General Microbiology 132, $277-287$.

Tochikubo, K., Kozuka, S. \& Yasuda, Y. (1988). Permeability of gentamicin into the inside of Bacillus subtilis spores. FEMS Microbiology Letters 50, 137-140.

VARY, J. C. (1973). Germination of Bacillus megaterium spores after various extraction procedures. Journal of Bacteriology 116, 797-802.

WATABE, K., ICHIKAWA, T. \& KonDO, M. (1974). Biochemical studies on germination of bacterial spores. I. Incorporation of ${ }^{14} \mathrm{C}$-L-alanine into spores of Bacillus thiaminolyticus during germination. Japanese Journal of Microbiology 18, 173-180.

WIRTZ, R. (1908). Eine einfache Art der Sporenfärbung. Zentralblatt für Bakteriologie, Parasitenkunde und Infektionskrankheiten. Abteilung 1, Originale 46, 727-728. 